\title{
Tactics for Applying Sustainable Management to Agroecosystems
}

\author{
Luis Eduardo Pontes Stefanelli ${ }^{1 *}$, Ramon Garcia de Marchi $^{2}$, Caroline de Cássia Gallo ${ }^{3}$, Raphael Vacchi Travaglini ${ }^{4}$ \\ ${ }^{1}$ Plant Protection, São Paulo State University (Botucatu), São Paulo, Brazil \\ ${ }^{2}$ Under Graduated Student, São Paulo State University (Botucatu), São Paulo, Brazil \\ ${ }^{3}$ Master Student Researcher, Wild Animals Post Graduated Program, São Paulo State University (Botucatu), São Paulo, Brazil \\ ${ }^{4}$ Independent Researcher, Dr. in Agronomist, Plant Protection, São Paulo State University (Botucatu), São Paulo, Brazil
}

*Corresponding Author: Luis Eduardo Pontes Stefanelli, São Paulo State University, Botucatu, São Paulo, Brazil.

Received: October 28, 2019; Published: November 29, 2019

DOI: 10.31080/ASAG.2019.03.0731

\begin{abstract}
The pursuit of increasingly sustainable agriculture is a recurring concern worldwide. Sustainability is a global obligation as many of our planet's resources are limited. This review addresses some of the tactics used by Brazilian farmers to achieve better yields without causing major impacts on agroecosystems. Today the challenge is to practice an increasingly efficient agriculture respecting the values of sustainability.
\end{abstract}

Keywords: Agriculture; Management; Control; Methods; Pest; Alternative

\section{Introduction}

The large amount of pesticides used for the control of diseases, pests and invasive plants, has generated major impacts on ecosystems, and there is a strong influence of pesticide active ingredients on ecological chains. Several environmental problems such as contamination of soil, water, food produced and poisoning organisms. Some of the active principles of pesticides can generate major disturbances in different Brazilian biomes, among some of these environmental impacts we can mention the biological imbalance; nutrient and organic matter cycling; reduction of beneficial organisms such as natural enemies and pollinators, reduction of biodiversity. All these implications raise societal concern about the impact of agriculture and contamination of the food chain, creating a growing demand for products with fewer agrochemical residues [17].

Among the ways to reduce, the use of pesticides is the use of conservationist practices in the use of agricultural and forest areas, the application of tools such as natural biological control, the use of plant extracts and other methods of pest and disease control.
However, just replacing a chemical with a biological one is not enough, it is necessary to involve the proper management of available natural resources, thus avoiding further degradation of the environment, conventional systems should therefore be less dependent on chemicals and other inputs, and use more biological processes in production systems, so that a more sustainable cultivation occurs.

\section{Diversification of cultivated area}

In addition to being the main component of natural ecosystems, biodiversity also promotes a number of ecological services that can even be quantitative measured and applied to ecosystem management [11]. Biodiversity functionality and abundance depend mainly on characteristics such as management intensity, degree of isolation, permanence of different crops over time, and diversity of vegetation within a cropping system. Among these characteristics, in studies researchers found that increasing diversity in production systems reduced the abundance of herbivory [1]. Following are some of the strategies for increasing biodiversity such as polyculture; crop intercropping, cover crops, green manures, genetic vari- 
ability, crop rotation, in particular, this tactic allows, among other benefits, such as improved soil characteristics and physical characteristics, such as nutrients not absorbed by a particular crop, either due to poor absorption efficiency or for other reasons, to be used by other crops and, from the decomposition of the straw, become available [3], in addition, nutrient release is directly linked to the physiology of each cover crop [27]. Other important factor is weed management, in this case competition with weeds causes large productivity losses in various crops, for example in wheat, leading to increased production costs with the use of herbicides, which makes the crop less and less economically attractive [21] and finally agroecosystem landscape diversification, in this topic it's important understand that landscape includes for example mountain, rivers, crops and etc.

\section{Polyculture}

Simultaneous cultivation of different taxonomic groups creates a heterogeneous environment often forming vegetation mosaics that make it difficult for the herbivore to locate the host plant (hypothesis of resource concentration), and negatively interfere with the establishment of pest populations [26]. The areas in general are smaller when compared to monoculture and have a greater number of species and biological interactions favoring natural biological control. Among the strategies used in plantations in polyculture, stands out the use of trap culture. For this, it is necessary to determine which the main crop is and the associated key pests, from which is planted next to this, another crop of greater preference for the insect.

\section{Culture consortia}

They are defined as associations of cultures in which two or more species with different cycles and vegetative architectures grow simultaneously. Crops are exploring concurrently in the same area and at the same time, without necessarily being sown at the same time. Arrangement of crops in space can be do in tillage, mixed tillage (no tiered arrangement), mosaic plots, alternate row tillage, and ground cover crops. The arrangement in time can be establish as simultaneous cultivation in sequence under synchronous or asynchronous and continuous/discontinuous conditions. The mechanisms involved in pest control through crop consortium diversification are due to direct or indirect action on pests. In direct action, one of the associated cultures imposes physicochemical barriers that make it difficult to locate, reproduce or colonize the host culture by the pest, by the presence of plant volatiles [22].

\section{Cover crops}

Cover crops are the cultivated or spontaneous vegetation that covers the soil, present along with the main crop. Cover crops are important mainly because they have numerous advantages such as less impact of raindrops (consequently less erosion), attenuation of temperature and humidity fluctuations. Vegetation mulches can also improve microbial activity and favor increased populations of natural enemies, particularly predatory insects [19].

\section{Plant material}

Farmers in various regions of the world to improve the physical, chemical and biological properties of arable land use plant material. In the case of Brazil in particular, due to available technologies, the farmer had the need to lose an agricultural crop to grow green manure. However, recent studies with this type of fertilization show that it is perfectly feasible to adopt this practice during the off-season periods (February/March to June/August) in the Center-South region, or still in consortium. Among the effects of green manure are increased organic matter content, higher nutrient availability, higher effective cation exchange capacity, decreased aluminum content, nutrient recycling and mobilization capacity, reduction in daily ranges of thermal variation and water in the topsoil, disruption of densified and compacted layers over time, increased infiltration capacity and water retention in the soil [3]. These effects are quite variable, depending on the species used, the management given to biomass, the time of planting and cutting of green manure, the residence time of the residues in the soil, the local conditions and the interaction between these factors [7]. In some cases species such as sunflower, crotalaria and guandu beans are major producers of nectar and pollen, thus attracting natural enemies in some production systems. Bees, in turn, improve the production and consequently the productivity of several agricultural crops. These plants attract and harbor a number of insects beneficial, which help in the control of citrus pests for example.

\section{Invasive plant management}

Invasive plant management is critical, practices such as weeding or selective weeding are important, as these plants serve as refuges and attraction factors for natural enemies. These plants may offer food resources, or serve as a place of refuge and oviposition. It can be said about invasive plant: A relevant role as competitor or host of pests, serving as a reservoir for crop infestations [13]. Some authors highlight the benefits of green manure in weed control [14], in this case it is observed that the management of host plants and other cultivation techniques can be used together. 
Agroecosystem landscape diversification

Changes in landscape structure, such as the reduction of natural vegetation fragments or isolation from the cultivation area, may alter the dispersal capacity of natural enemies, thus reducing the populations of other ecosystem organisms. Landscape diversification allows biodiversity rich habitats, some components of landscape structure can contribute to the increase of this biodiversity, and among these components, and we can mention the marginal vegetation strip, biological corridor and the edges of cultivation.

\section{Biological control}

Biological control is a natural phenomenon, the regulation of the number of plants and animals by natural enemies, the biotic agents of mortality. It involves the mechanism of reciprocal density, which acts in such a way that another population regulates always one population, that is, one living being is always exploited by another living being and with effect on the regulation of population growth, thus maintaining balance from nature [15,22]. Biological control was define as "the action of parasitoids, predators and pathogens in maintaining the density of another organism at a lower level than would normally occur in its absence [11,24].

\section{Parasitodies and predators}

- Parasitoids: Within the entomology the term parasitoid is consider, the insect that parasites a host, completes its cycle in a single host and usually kills that host. Their larvae exhibit parasitic habit, and the adults are free-living, feeding on nectar, sugary substances, etc. Parasitoids are mostly within the Order Hymenoptera, and few within the Order Diptera (Family Tachinidae). They attack and develop at all stages of insects, ie egg, larva (nymph), pupa and adult. Some examples of parasitoids, Trichogramma pretiosum, Cotesia flavipes, Telenomus podisi, Trissolcus basalis, Lysiphlebus testaceipes, Aphidius colemani.

- $\quad$ Predators: These are free-living individuals, usually larger than prey, requiring a large number of prey to complete their life cycle, and may exhibit predatory behavior in both the nymph (larval) and adult stages. As for eating habits can be chewing or sucking. They are present in several insect orders, the most important being Coleoptera (Coccinellidae, Carabidae), Diptera (Syrphidae, Asilidae), Hemiptera (Anthocoridae, Pentatomidae, Reduviidae), Neuroptera
(Chrysopidae Family), Hymenoptera (Vespidae Family), Dermaptera (Forficulidae Families, Labiduridae). Some examples of predatory insects, Orius insidiosus, Chrysoperla externa, Labidura riparia, Cycloneda sanguinea, Porasilus barbiellinii, Brachygastra lecheguana, Podisus nigrispinus, among others.

Following are some examples of biological control using natural enemies for pest control in Brazilian territory (Table 1).

\begin{tabular}{|c|c|c|c|}
\hline Crop & Natural enemies & Source & Pest \\
\hline $\begin{array}{l}\text { Sugar } \\
\text { cane }\end{array}$ & Cotesia flavipes & Introduced & Diatrea saccharalis \\
\hline Soybean & Trissolcus basalis & Native & Euschistus heros \\
\hline Tomato & $\begin{array}{c}\text { Trichogramma } \\
\text { pretiosum }\end{array}$ & Introduced & Tuta absoluta \\
\hline Wheat & Microhymenopter & Introduced & Aphids \\
\hline Pasture & $\begin{array}{c}\text { Neodusmetia } \\
\text { sangwani }\end{array}$ & Introduced & Antonina graminis \\
\hline
\end{tabular}

Table 1: Examples of biological control using natural enemies in Brazil.

Source: author

\section{Microbial control}

This type of control uses entomogenic microorganisms, with the use of mantle in the insect pest population at non-harmful levels of economic damage. It is important to stress that this control must be used in consortium with a set of other measures. This tool could be used in any Integrated Pest Management (IPM) program, below are some forms of this control, which are fungi, such as bacteria and entomopathogenic viruses [9].

\section{Entomopathogenic fungi}

In particular, fungal-based products, most often in these formulations or active ingredient is a conidial phase, or the onset of reproduction sexed by microorganism. Many of this fungi that occur naturally in the Brazilian territory, are capable of contaminating and infecting insects and mites, their action occurs mainly through the integument and other parts of insect biology. The formulated products are available in the domestic market as post-wettable granular (G) formulations (WP) and emulsifiable oil concentrated (SC) suspensions [4]. These products may be used in the form of spraying, dusting, irrigation or even mixing with organic sub- 
strates. Some fungi with different commercial formulations can be found as Nomuraea rileyi, for control of Anticarsia gemmatalis caterpillars in soybean culture. In Table 2, you can see fungi like Metarhizium anisopliae, Beauveria bassiana and Verticillium lecanii for pest control such as leafhoppers, termites and whitefly for example [5].

\begin{tabular}{|c|c|c|c|}
\hline Product & Patógeno & Pest & Country \\
\hline Rice + fungi & $\begin{array}{c}\text { Metarhizium } \\
\text { anisopliae }\end{array}$ & Leafhopper & Brazil \\
\hline Rice + fungi & $\begin{array}{c}\text { Sporothrix } \\
\text { ansectorum }\end{array}$ & Pentatomidae & Brazil \\
\hline Boveril & $\begin{array}{c}\text { Beuveria } \\
\text { bassiana }\end{array}$ & Termites & Brazil \\
\hline Hongo & $\begin{array}{c}\text { Beuaveria } \\
\text { Brongniartii }\end{array}$ & $\begin{array}{c}\text { Gorgulho- } \\
\text { dos-andes }\end{array}$ & Peru \\
\hline Mycotal & $\begin{array}{c}\text { Verticillium } \\
\text { lecanii }\end{array}$ & White-fly thrips & Netherlands \\
\hline
\end{tabular}

Table 2: Some fungal products developed by industries and research centers.

Source: Alves, 1998 (adapted).

\section{Entomopathogenic bacteria}

A large number of bacterial species can occur that are capable of attacking insects. The most important is Bacillus thuringiensis and its other varieties. This species of bacteria is capable of producing protein spores and crystals by penetrating the insect via the oral route. Table 3 presents some commercial products based on entomopathogenic bacteria.

\section{Entomopathogenic viruses}

In Brazil, the control of caterpillars in crops is very important, particularly in crops such as soybeans and corn. Entomopathogenic viruses are a promising alternative in the Brazilian territory, the use of Baculovirus anticarsia in soybean (Glycine max L.) crops that is a plant of Chinese origin, with macerated infected caterpillars diluted with water. This type of nuclear polyhedrosis virus (NVP), had been use with great success to control Anticarsia gemmatalis (soybean caterpillar), another NVP used is Spodoptera frugiperda in cornfields. In Table 4, here are some commercially developed virus-based products.

\begin{tabular}{|c|c|c|c|}
\hline Product & Pathogen & Pest & Company \\
\hline Baculo-soja & NVP & $\begin{array}{c}\text { Anticarsia } \\
\text { gemmatalis }\end{array}$ & $\begin{array}{c}\text { Nova Era, } \\
\text { Brasil }\end{array}$ \\
\hline GEMSTARLC & NVP & $\begin{array}{c}\text { Helicoverpa e } \\
\text { Heliothis }\end{array}$ & Biosys, Eua \\
\hline SPOD-XLC & NVP & $\begin{array}{c}\text { Spodoptera } \\
\text { frugiperda }\end{array}$ & Biosys, Eua \\
\hline
\end{tabular}

Table 4: Some virus-based products developed by industries and research centers.

Source: Alves, 1998 (adapted).

Entomopathogenic nematodes

We can cite some genera with great potential use such as Steinernema and Heterohabditis mainly for the control of various agricultural pests. Below are Table 5 for some nematode-based products.

\begin{tabular}{|c|c|c|c|}
\hline Product & Pathogen & Pest & Company \\
\hline Larvanem & Heterohabditis megidis & Bug & Koppert \\
\hline Nematoden & Heterohabditis spp. & Bug & $\begin{array}{c}\text { Adermatt } \\
\text { Biocontrol }\end{array}$ \\
\hline Termask & $\begin{array}{c}\text { Steinernema carpocap- } \\
\text { sae }\end{array}$ & $\begin{array}{c}\text { Ter- } \\
\text { mite }\end{array}$ & $\begin{array}{c}\text { Better } \\
\text { Yelds } \\
\text { Insects }\end{array}$ \\
\hline
\end{tabular}

Table 5: Developed nematode products.

Source: Alves, 1998 (adapted).

\section{Botanical or natural insecticides}

Some plants are naturally resistant to insect damage as they produce compounds that are toxic or disrupt the life cycle of these organisms [6]. Botanical insecticides are compounds resulting from the secondary metabolism of plants that make up the chemical defense itself against herbivorous insects [20].

These substances, called secondary compounds, or allelochemicals [31], are biosynthetically derived compounds of primary metabolites and have no apparent function, but have an important ecological role serving, among others, as a chemical defense against microorganisms, insects and predators [18]. 
Most of these metabolites could be obtain from plant parts by distillation or extraction with organic or aqueous solvents [2]. It is noted that the active principle of botanical insecticides could be derived from the whole plant.

The evolution of food preferences in phytophagous insects is greatly influence by the development of these secondary metabolites [23]. Some of these metabolites produced may be repellent, suppressing, deterring, intoxicating or digestion reducing.

The use of insecticide plants in pest control is not a recent technique. Among the first known botanical insecticides are pyrethrin, an active ingredient extracted from flowers of the genus Chrysanthemum (family Compositae), and also nicotine, an alkaloid extracted mainly from tobacco leaves, Nicotiana tabacum (family
Solanaceae), another active with great Potential is rotenone, extracted from the roots, leaves, branches or seeds of Tephrosia candida. Other plant extracts of the Liliacea family such as Schoenocaulon officinale, Allium cepa and Allium sativum also showed optimistic results. In works by several researchers, it is mentioned that the most promising botanical derivatives belong to the families Meliaceae, Rutaceae, Asteraceae, Annonaceae, Malvaceae, Labiatae and Canellaceae. Among these, the families Meliaceae and Rutaceae, of the order Rutales, are the most studied due to the presence of biologically active limonoids against a wide variety of insects [10]. Neem (Azadirachta indica) is a Meliaceae currently considered the most important insecticide plant, presenting a series of chemical compounds whose azadiractin is the most active [28]. Table 6 below presents some plants used by the producers.

\begin{tabular}{|c|c|c|c|c|}
\hline Popular name & Scientific name & Used Part & Use & Application \\
\hline Garlic & Allium sativum & Bulbs & Extract & Mining larva \\
\hline Onion & Allium cepa & Bulbs & Extract & Mining larva \\
\hline Rue & Ruta graveolens & Plant & Repellency & Insecticide \\
\hline Manioc & Manihot esculenta & Root & Extract & Insecticide \\
\hline Basil & Ocimum basilicum & Leaf & Extract/Repellency & Insecticide \\
\hline Neem & Azadirachta indica & Leaf & Isolate extract & Insecticide \\
\hline Chili & Capsicum sp. & Fruit & Extract & Slug \\
\hline Pine cone & Annona squamosal & Seed & Extract & Insecticide \\
\hline
\end{tabular}

Table 6: Some Plants used as repellents or as extracts for alternative pest control.

\section{Source: author}

\section{Fertilization}

Balanced fertilization allows for better plant development, [25] researchers observed that stressed plants have less ability to synthesize defense chemicals and the combination of this factor with increased nutritional availability makes the plant particularly vulnerable to herbivore attack. In addition to the essential nutrients for the plant to complete its development, there are also beneficial elements such as cobalt and silicon, which can act on the physiological mechanisms of the crop acting as elicitors or resistance inducers, as found [16] in studies of application of silicon in corn crop and its influence on the cartridge caterpillar. Thus, these mechanisms may represent the potential benefits: Increase of phenolic compounds and cell wall resistance; increases photosynthesis; decreases pest incidence; upright plants; decreases sweating

\section{Complementary controls}

Complementary controls that could be used in conjunction with other controls, however, usually have some kind of limitation in their use, among them we can mention:

Fire

This technique has a restricted use in pest control, however sometimes this alternative is used in cases where chemical control has no economic advantages; this tactic is also used to complement other methods. Farmers use fire to control clouds of locusts, mealybugs, weevils and sugarcane leafhoppers and cotton boll weevils. Due to some environmental laws, the burning of sugarcane fields is currently prohibit. 
Drainage

Drainage is a tactic used in special cases, such as swamp ecosystems, this type of control is performed for the control of aquatic weevils in irrigated rice crop.

\section{Inundation}

This technique is also used in rice cultivation for pest control, such as grubs.

\section{Temperature}

This control consists of using high temperatures (above $50^{\circ} \mathrm{C}$ ) or low temperatures (below $5^{\circ} \mathrm{C}$ ) to generate mortality or paralyze the activities of pest insects. The high temperatures generate protein denaturation, harming the body's physiology. Cold temperatures slow down your metabolic activities. This control method is widely used in pest control of stored products (cereals in general).

\section{Conclusion}

All alternative control methods approached have great potential and undoubtedly represent a new path for Brazilian agriculture. Due to the indiscriminate use of pesticides, there is a need to develop new proposals or rescue old concepts.

The growing interest in organic products, food safety and environmental issues raises the awareness of producers and consumers. All these aspects drive the search for alternative management in different ecosystems. All of them improve the complexity of the environment and are more sustainable. For this reason, the new way is to do the correct management of pest. We can still cite some tools that have been widely used lately, such as the use of sexual or aggregation pheromones $[8,29,30]$ in the management of certain pests. This is a technique that has been especially successful in monitoring the pest population. In short, biological control will probably be provided with resources and inputs by most companies and research centers, aiming at a more sustainable management of agro-ecosystems.

\section{Acknowledgements}

"This study was financed in part by the Coordenação de Aperfeiçoamento de Pessoal de Nível Superior - Brasil (CAPES) - Finance Code 001".

\section{Conflict of Interest}

The authors declare that there was no conflict of interest.

\section{Bibliography}

1. Andow, DA. "Vegetational diversity and arthropod population response”. Annual review of entomology 36.1 (1991): 561-586.

2. Aguiar-Menezes E. "Inseticidas botânicos: seus princípios ativos, modo de ação e uso agrícola”. Embrapa Agrobiologia (2005).

3. Alcântara FA., et al. "Adubação verde na recuperação da fertilidade de um Latossolo Vermelho-Escuro degradado". Pesquisa Agropecuária Brasileira 35.2 (2000).

4. Almeida JEM., et al. "Formulação de entomopatógenos na América Latina”. Controle microbiano de pragas na América Latina (2008): 257-277.

5. Alves SB. "Controle microbiano de insetos". (1998).

6. Arnason JT., et al. "Naturally occurring and synthetic thiophenes as photoactivated insecticides". Insecticides of plant origin 387 (1989): 164-172.

7. Borkert CM., et al. "Nutrientes minerais na biomassa da parte aérea em culturas de cobertura de solo". Pesquisa Agropecuária Brasileira 38.1 (2003): 143-153.

8. Campion, DG. "Survey of pheromone uses in pest control". Techniques in pheromone research. Springer, New York, NY (1984): 405-449.

9. Chaboussou F. "Plantes malades des pesticides; bases nouvelles dune prevention contre maladies et parasites". Debard (1980).

10. Champagne., et al. "Insecticidal activity of phytochemicals and extracts of the Meliaceae". Insecticides of plant origin 387 (1989): 95-109.

11. Costanza R., et al. "The value of the world's ecosystem services and natural capital”. Nature 387.6630 (1997): 253.

12. DeBach P., et al. "Biological control of coccids by introduced natural enemies". Biological control. Springer, Boston, MA (1971): 165-194.

13. Durigan, JC and RA Pitelli. "A importância das plantas daninhas no manejo integrado de pragas da cultura de citros". SEMINÁRIO INTERNACIONAL DE CITROS-MIP 3 (1994): 277-290. 
14. Fontanétti A., et al. "Adubação verde no controle de plantas invasoras nas culturas de alface-americana e de repolho". Ciência e Agrotecnologia 28.5 (2004): 967-973.

15. Gallo D., et al. "Entomologia agrícola”. (2002).

16. Goussain, MM., et al. "Efeito da aplicação de silício em plantas de milho no desenvolvimento biológico da lagarta-do-cartucho Spodoptera frugiperda (JE Smith)(Lepidoptera: Noctuidae)". Neotropical Entomology (2002).

17. Grisolia CK. "Agrotóxicos: mutações, reprodução and câncer; riscos ao homem e ao meio ambiente, pela avaliação de genotoxicidade, carcinogenicidade e efeitos sobre a reprodução". Ed. UnB, 2005.

18. Harborne JB. Introduction to ecological biochemistry. Academic press, (2014).

19. Hartwig NL and UA Hans. "Cover crops and living mulches". Weed science 50.6 (2002): 688-699.

20. Kim SI., et al. "Insecticidal activities of aromatic plant extracts and essential oils against Sitophilus oryzae and Callosobruchus chinensis". Journal of Stored products research 39.3 (2003): 293-303.

21. Lamego FP., et al. "Habilidade competitiva de cultivares de trigo com plantas daninhas". Planta Daninha 31.3 (2013): 521-531.

22. Nicholls CI., et al. "Manual practico de control biologico para una agricultura sustentable". University of California, California (EUA). (1999).

23. Panizzi AR and Parra JRP. "Ecologia nutricional de insetos e suas implicações no manejo de pragas". (1991).

24. Parra JRP., et al. "Controle biológico: terminologia". Controle Biológico no Brasil: parasitóides e predadores. São Paulo. Manole editora (2002): 1-16.

25. Rhoads DF and Bergdahl JC. Adaptive significance of toxic nectar. The American Naturalist. 117.5 (1981): 798-803.

26. Root RB. "Organization of a plant-arthropod association in simple and diverse habitats: the fauna of collards (Brassica oleracea)". Ecological monographs 43.1 (1973): 95-124.
27. Stefanelli LEP and Moreno JLT. "AVALIAÇÃO DA LIBERAÇÃO DE NUTRIENTES DE ADUBOS VERDES”. V JORNACITEC”. (2016).

28. Vendramin ME., et al. "Chemical constituents from the leaves of Annona rugulosa (Annonaceae)”. Biochemical Systematics and Ecology 49 (2013): 152-155.

29. Vilela EF. “Adoção de feromônios no manejo integrado de pragas". Pesquisa Agropecuária Brasileira 27.13 (1992): 313-318.

30. Weatherston I., et al. "Alternative dispensers for trapping and disruption". Insect Pheromones in Plant Protection. John Wiley and Sons, New York, NY (1989): 249-227.

31. Whittaker RH. "The biochemical ecology of higher plants". Chemical ecology 3 (1970): 43-70.

\section{Volume 3 Issue 12 December 2019 (C) All rights are reserved by Luis Eduardo Pontes Stefanelli., et al.}

